громадської думки, розвиток особистості тощо) та забезпечувати їх включення в ії ціннісну ієрархію, що приведе до певного вибору моделі поведінки, а це, у свою чергу, буде сприяти адекватному сприйняттю особливостей i можливостей гендерної політики в системі поліції, визначенню завдань гендерної політики на всіх рівнях, розвитку відповідального ставлення до ії проведення, а відтак - впливатиме на якість гендерної політики.

\title{
Література:
}

1. Кобелянська Л. 50/50: сучасне гендерне мислення : словник / Л. Кобелянська, Т. Мельник. - К. : К.І.С., 2005. - 280 с.

2. Про забезпечення рівних прав та можливостей жінок і чоловіків: Закон України від 08.09.2005 р. № 2866-15 / Відомості Верховної Ради України, 2005, № 52, ст.561 .

3. Філософський енциклопедичний словник / В. І. Шинкарук (гол. редкол.) та ін. -: Інститут філософії ім. Григорія Сковороди НАН України : Абрис. Київ, 2002. - 742 с.

4. Грицяк Н. Формування гендерної політики в Україні: проблеми теорії, методології, практики : монографія / Наталя Грицяк. - К. : Вид-во НАДУ, 2004. - 384 с.

5. Кулачек О. Роль жінки в державному управлінні: старі образи, нові обрії : [монографія] / Ольга Кулачек. - К. : Вид-во Соломії Павличко “Основи”, 2005. - 304 с.

DOI https://doi.org/10.30525/978-9934-26-148-0-34

\section{ТЕОРЕТИКО-ПРИКЛАДНІ ПРОБЛЕМИ ВПРОВАДЖЕННЯ ПОДАТКОВОЇ АМНІСТІЇ В УКРАЇНІ}

\author{
Майка М. Б. \\ адвокат, кандидат юридичних наук, доцент кафедри права \\ Галищького коледжу імені В 'ячеслава Чорновола
}

\section{Глива А. О.}

студентка

Галицького коледжу імені В 'ячеслава Чорновола

м. Тернопіль, Україна

Вступ. Кризові явища як у світовій, так і в національній економіці, які загострилися через пандемію Covid-19, призвели до проблем залучення додаткових ресурсів в економіку кожної країни світу. 
Високий рівень тіньової економіки, що і до сьогоднішнього дня $є$ важливим джерелом надходжень населення, витрати яких значною мірою перевищують офіційні доходи, негативно позначається на всіх макроекономічних показниках розвитку держави. Фінансово-правовими чинниками тінізації економіки та, як наслідок, обігу значної частини готівки поза банківською системою, науковці сучасності визначають: неефективність державного регулювання економіки; недосконалість та нестабільність податкового законодавства, правова незахищеність платників податків, неефективне адміністрування податків; відсутність дієвої системи контролю ринку праці та співмірного покарання за незаконне працевлаштування; недостатне грошово-кредитне регулювання, надмірний обсяг грошових пропозицій, нестабільний валютний курс; недосконалість бюджетної системи та системи контролю за використанням бюджетних коштів; недоліки правоохоронної та судової системи [3].

Тіньова економіка викликає доволі високий рівень корупції у державних органах влади, як на місцевому, так і державному рівні. Важливою проблемою, з приводу якої періодично піднімається питання, $\epsilon$ відтік капіталів за межі країни. За різними оцінками, за останні десять років з економіки України виведено від 50 до 100 млрд доларів США, які здебільшого розміщені в офшорних зонах, про що свідчать останні викриття інформації в мережі Internet стосовно власників капіталів, які знаходяться в офшорних зонах [4]. Саме одним із шляхів протидії вказаним вище негативним явищам національної економіки $\mathrm{i} \epsilon$ проведення податкової амністії до якої вдавалися багато країн світу, що відносяться як до розвинених держав, так і до держав, які розвиваються.

Мета наукового дослідження полягає у визначенні та доктринальній розробці проблем впровадження податкової амністії в Україні.

Матеріали та методи дослідження. При дослідженні застосовано загальні та спеціальні методи дослідження, використано доктринальні правові джерела (наукові роботи та дисертаційні дослідження науковців сучасності), матеріали та статистичні дані закордонних держав.

Результати та обговорення. Нормами Закону України «Про внесення змін до Податкового кодексу України щодо стимулювання детінізації доходів та підвищення податкової культури громадян шляхом запровадження одноразового (спеціального) добровільного декларування фізичними особами належних їм активів та сплати одноразового збору до бюджету» № 1539-IX від 15 червня 2021 року [1] передбачено декларування фізичною особою належних їй активів, якщо такі активи були одержані (набуті) за рахунок доходів, що підлягали в момент їх 
нарахування (отримання) оподаткуванню в Україні та 3 яких не були сплачені або сплачені не в повному обсязі податки і збори відповідно до вимог законодавства 3 питань оподаткування, що мали місце до 1 січня 2021 року.

Аналіз міжнародного досвіду «нульового декларування» вказує, що податкова амністія є доволі неоднозначним інструментом формування дохідної частини бюджету держави, особливо у контексті довгострокового впливу на дотримання вимог податкової дисципліни, та підтверджує інституційну неспроможність держави щодо здійснення належного контролю за дотриманням відповідного законодавства, притягнення винних до персоніфікованої відповідальності за його порушення, замінюючи ії колективною відповідальністю, що ставить добросовісних платників податків у нерівне становище з громадянами, які ухилялися від сплати податків та використовували неоподатковані доходи для власного збагачення. Зазначені фактичні обставини, не відповідають конституційному обов'язку кожного сплачувати податки і збори та не відповідає податковому принципу «рівності усіх платників податків перед законом, недопущення будь-яких проявів податкової дискримінації» [2].

На підставі аналізу нормативних положень та сучасної правової доктрини, серед недоліків правового регулювання Закону України № 1539-ІХ від 15 червня 2021 року відзначаємо: відсутність механізму стимулювання суб'єктів декларування щодо подання «нульової декларації»; недостатній рівень фактичних та правових гарантії непритягнення суб'єктів декларування за виявлені порушення та злочини в сфері податків і обігу валюти; не достатня визначеність бази нарахування (на момент подання декларації чи на момент придбання майна) спеціального збору, що справляється з вартості наявного у платника податків майна; відсутність мотивування позбавлення права на одноразове декларування осіб, які виконували «публічні функції». Податкова амністія створює ризики виникнення соціальних конфліктів у суспільстві, підриває довіру громадян до держави, формує відповідну мотиваційну поведінку на майбутнє, що у підсумку може мати значно більші негативні наслідки, аніж короткочасні фінансові вигоди у вигляді бюджетних надходжень. Подібній амністії має передувати реформування системи оподаткування доходів фізичних осіб, удосконалення адміністрування податків і зборів, реформування податкових, митних, правоохоронних органів та судової системи, а також забезпечення державних гарантій щодо власності громадян, зокрема через неухильне дотримання законодавства про персональні дані. Незрозуміло, яким чином легалізовані кошти враховуватимуться контролюючими 
органами та як буде проводитися перевірка таких фізичних осіб суб'єктами фінансового моніторингу. Механізм анонімного декларування виключає можливість держави відмежувати діяння щодо ухилення від сплати податків від інших правопорушень (а тому може слугувати способом легалізації «брудних» грошей) та перевірити правильність визначення бази оподаткування у випадку спеціального декларування, що може призвести до мінімізації податкових зобов'язань.

Для покращення ефективності податкової амністії, вважаємо необхідним:

- встановити механізм стимулювання суб'єктів декларування щодо подання «нульової декларації»;

- розширити фактичні та правові гарантії непритягнення суб'єктів декларування за виявлені порушення та злочини в сфері податків і обігу валюти;

- деталізувати базу нарахування (на момент подання декларації чи на момент придбання майна) спеціального збору, що справляється 3 вартості наявного у платника податків майна;

- диверсифікувати право на одноразове декларування осіб, які виконували «публічні функції».

Таким чином, встановлення державою у законодавчому акті способів «нульового декларування», створює передумови для детінізації економіки, водночас, правове регулювання податкової амністії в редакції Закону України № 1539-IX від 15 червня 2021 року несе також і суттєві ризики для їі успішної реалізації.

\section{Література:}

1. Закон України «Про внесення змін до Податкового кодексу України щодо стимулювання детінізації доходів та підвищення податкової культури громадян шляхом запровадження одноразового (спеціального) добровільного декларування фізичними особами належних їм активів та сплати одноразового збору до бюджету» № 1539-IX від 15 червня 2021 року. URL: http://zakon.rada.gov.ua (дата звернення: 25.09.2021).

2. Кисляк Р. Ухвалена податкова амністія. Які в ній сховані ризики. URL: https://finclub.net (дата звернення 25.09.2021).

3. Майка М.Б., Денисюк В.О. Фінансово-правові механізми детінізації економіки України: організаційний аспект. URL: https ://sci- conf.com.ua (дата звернення 25.09.2021). 
4. Шульга Т.М., Кононенко Л.В. Податкова амністія в Україні в контексті світового досвіду. URL: https://osau.edu.ua/ (дата звернення 25.09.2021).

DOI https://doi.org/10.30525/978-9934-26-148-0-35

\title{
ЗАБЕЗПЕЧЕННЯ НОРМАТИВНО-ПРАВОВОГО РЕГУЛЮВАННЯ ОБІГУ КРИПТОВАЛЮТ В УКРАЇНІ ЯК ОСНОВА ПРОТИДІЇ ЇХ ПРОТИПРАВНОМУ ВИКОРИСТАННЮ
}

\author{
Мельник Д. С. \\ кандидат юридичних наук, дочент кафедри права \\ ПЗВО «Міжнародний класичний університет імені Пилипа Орлика»
}

\section{Петрова О. С.}

здобувач вищчої освіти 2 курсу спеціальності 081 Право ПЗВО «Міжнародний класичний університет імені Пилипа Орлика» м. Миколаїв, Україна

Світові процеси глобалізації та стрімкий розвиток інформаційних технологій зумовили виникнення нових загроз національній безпеці України у фінансовій, інформаційній та інших сферах.

Зокрема, сучасні світові тенденції свідчать про активне використання криптовалют у протиправній діяльності - легалізації доходів, одержаних злочинним шляхом, фінансування терористичної й сепаратистської діяльності, посягань на конституційний лад та державну владу, протиправного виведення капіталів за кордон, внаслідок чого виникають численні загрози та ризики для національної безпеки багатьох держав світу, у т.ч. й України.

Зокрема, Міністерство юстиції США заявило про викриті факти використання РФ криптовалют для фінансування ведення підривної діяльності на американській території, у т.ч. хакерські атаки на державні установи протягом 2014 - 2018 років та втручання у вибори Президента США у 2016 році. Також у звіті Мін'юсту США про боротьбу 3 торгівлею наркотиками за 2017 рік зазначено про використання операцій з криптовалютами для відмивання коштів, отриманих злочинним шляхом. У грудні 2017 року Федеральною прокуратурою США спільно з Об'єднаним АТЦ ФБР (м. Нью-Йорк) викрито факт використання 